\title{
Expression and function of ErbB receptors and ligands in the pituitary
}

\author{
Odelia Cooper ${ }^{\star}$, George Vlotides ${ }^{1 *}$, Hidenori Fukuoka, Mark I Greene ${ }^{2,3}$ \\ and Shlomo Melmed
}

Department of Medicine, Pituitary Center, Cedars-Sinai Medical Center, Academic Affairs, Room 2015, 8700 Beverly Boulevard, Los Angeles, California 90048, USA

${ }^{1}$ Department of Medicine II, University-Hospital Munich-Grosshadern, University of Munich, Munich, Germany

${ }^{2}$ Department of Biomedical Science and Pathology and Laboratory Medicine, Cedars-Sinai Medical Center, Los Angeles, California, USA

${ }^{3}$ Department of Pathology and Laboratory Medicine, University of Pennsylvania, Philadelphia, Pennsylvania, USA

(Correspondence should be addressed to S Melmed; Email: melmed@cshs.org)

*(O Cooper and G Vlotides contributed equally to this work)

\begin{abstract}
The role of ErbB family in discreet pituitary functions is reviewed. Several ErbB receptor ligands, EGF, TGF $\alpha$, and heregulin are differentially expressed in normal gonadotroph and lactosomatotroph lineages, and other elements of the anterior pituitary. ErbB receptors, i.e. EGFR and ErbB2, are also localized to the anterior pituitary with preferential EGFR lactosomatotroph expression. EGF regulates $\mathrm{CRH}$ and $\mathrm{ACTH}$ secretion and corticotroph proliferation as well as exhibiting autocrine and paracrine effects on gonadotrophs and on lactosomatotroph proliferation, gene and protein expression, and hormonal secretion. EGF and EGFR are expressed in both functioning and non-functioning pituitary adenomas, with higher expression in more aggressive tumor subtypes. ErbB2 receptor is detected in all tumor subtypes, particularly in invasive tumors. ErbB tyrosine kinase inhibitors regulate hormonal secretion, cell morphology, and proliferation in lacto-somatotroph tumors, reflecting the emerging application of targeted pituitary therapeutics.
\end{abstract}

Endocrine-Related Cancer (2011) 18 R197-R211

\section{Introduction}

Pituitary tumors are monoclonal adenomas accounting for $\sim 15 \%$ of primary intracranial neoplasms. Although usually benign, excess hormone secretion may lead to distinct endocrine syndromes such as acromegaly, Cushing's disease, and hyperprolactinemia, while non-functional tumors lead primarily to hypogonadism and critical compressive symptoms (Melmed 2003). Dopamine agonist and/or somatostatin analog therapy of tumors arising from the lactosomatotroph cell lineage is effective in most tumors though less effective in tumors manifesting drug resistance. No effective pituitary targeted drug therapies are currently available for ACTH-secreting or non-functional adenomas (Melmed 2003, 2009). Alternative treatment options are required for recurring invasive macroadenomas and for infrequently encountered but aggressive pituitary carcinomas resistant to most currently available treatments (Kaltsas et al. 2005, Scheithauer et al. 2005).

Over the last two decades, the EGFR pathway has been explored in both pituitary physiology and pathology. The human epidermal growth factor receptor (EGFR, ErbB, and HER) family comprises four known members EGFR (ErbB1 and HER1), p185 ${ }^{\mathrm{Her} 2 / \mathrm{neu}}$ (ErbB2 and HER2), ErbB3 (HER3), and ErbB4 (HER4), which are transmembrane glycoprotein receptors containing an extracellular ligandbinding domain and an intracellular tyrosine kinase domain (Fig. 1). Aberrant receptor expression, mutations, or overexpression lead to receptor homoor heterodimerization, activation of the intrinsic tyrosine kinase and subsequent induction of specific intracellular signaling cascades (Zhang et al. 2007). Activating ligands include epidermal growth factor (EGF), transforming growth factor (TGF)- $\alpha$, 


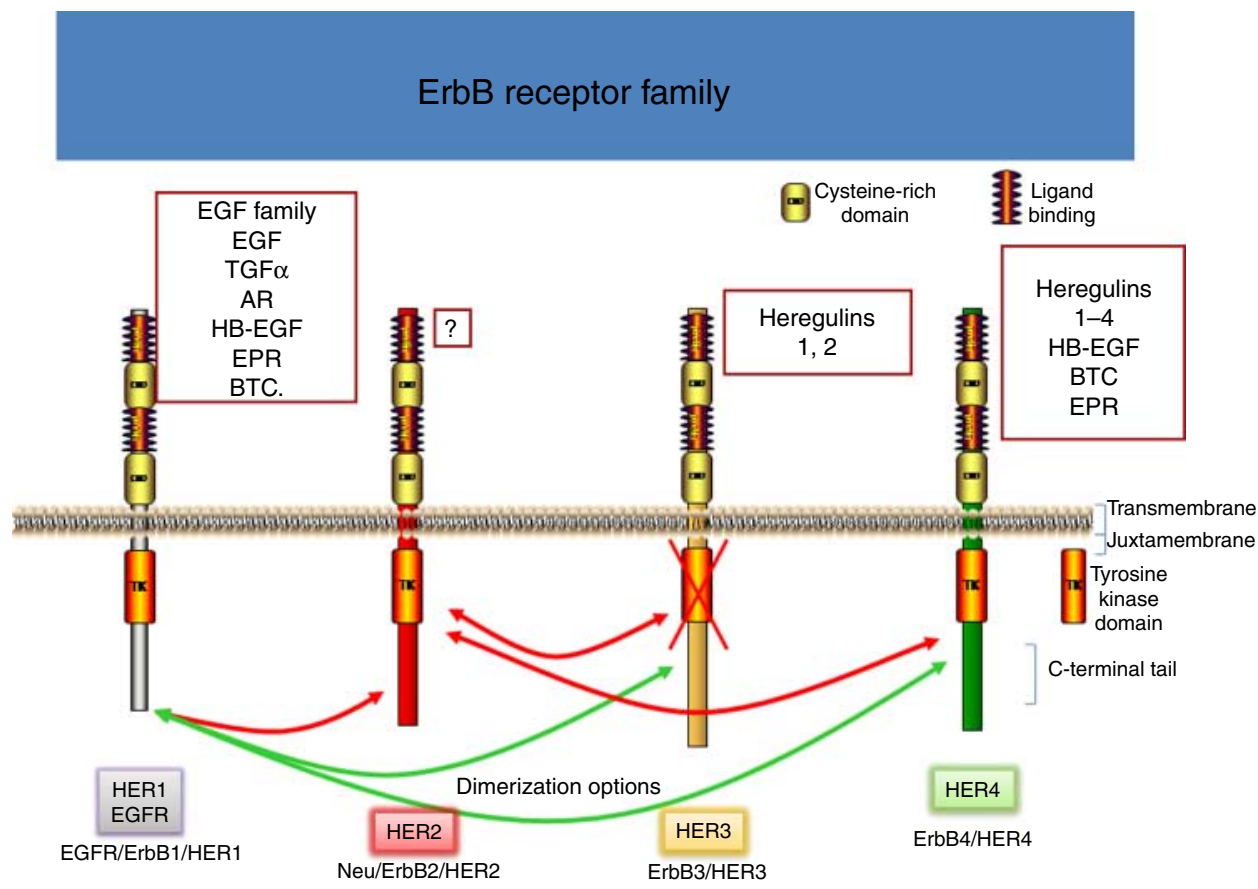

Figure 1 ErbB receptor family. ErbB receptor family consists of four closely related type 1 transmembrane tyrosine kinase receptors, EGFR, ErbB2, ErbB3, and erbB4. EGFR and erbB4 have active tyrosine kinase domains and known ligands, ErbB3 can bind to several heregulins as ligands but lacks tyrosine kinase activity. By contrast, ErbB2 possesses an active tyrosine kinase domain but no ligand has been identified. This receptor exists in the active conformation state, so this receptor is constitutively available for dimerization. Ligand binding to ErbB receptors induces the formation of receptor homo- and heterodimers and activation of the intrinsic kinase domain, resulting in phosphorylation on specific tyrosine residues. These phosphorylated residues serve as docking sites for a range of proteins, the recruitment of which leads to the activation of intracellular signaling pathways. Full colour version of this figure available via http://dx.doi.org/10.1530/ERC-11-0066.

amphiregulin (AR), heparin-binding EGF (HB-EGF), betacellulin, epiregulin (ER), and heregulins (HRG, neuregulins (NR); Zhang et al. 2007). Increased ErbBreceptor kinase activity has been implicated in the pathogenesis of several human cancers. Selective therapeutic targeting particularly of EGFR and p185 her2/neu with monoclonal antibodies and small compound tyrosine kinase inhibitors (TKIs; Zhang et al. 2007) has exhibited therapeutic efficacy.

This review critically appraises the role of the ErbB family in pituitary development and tumorigenesis to heighten awareness of this growth factor family that may lead to novel medical therapy for pituitary tumors.

\section{Anterior pituitary tissue}

\section{EGFR ligands and receptor}

Initial studies examined whole pituitaries for expression of ErbB ligands and distinguished that EGF localizes to the anterior and not posterior pituitary (Kasselberg et al. 1985), present at all stages of development from fetus to adulthood (Kasselberg et al. 1985) and confirmed by PCR (LeRiche et al. 1996), immunohistochemistry (IHC; Kajikawa et al. 1991), radio-receptor-binding assay, and western blot (WB) of autopsy-derived human pituitaries (Halper et al. 1992). Examination of male mouse pituitaries by in situ hybridization (ISH) revealed EGF mRNA in the anterior and intermediate lobes (Honda et al. 2000); EGF mRNA-expressing cells were medium-sized and round, making up to $40 \%$ of the total number of secretory cells (Honda et al. 2000). These cells functionally secrete EGF, confirmed on reverse hemolytic plaque assays and IHC of rat anterior pituitary plurihormonal cells (Mouihate \& Lestage 1995a,b, Mouihate et al. 1996b).

$T G F \alpha$ mRNA has been demonstrated in both animal and human pituitary tissue. It is expressed in the rat anterior pituitary as detected by ribonuclease protection assay, RT-PCR (Fan et al. 1995) and ISH immunocytochemistry (ICC; Fan \& Childs 1995), in intact bovine anterior pituitary gland and cell cultures (Mueller et al. 1989), and in all adenohypophysial cell types in human normal pituitary tissue (Ezzat et al. 1995). TGF $\alpha$ expression increases in response to 12-O-tetradecanoylphorbol-13-acetate and 
EGF (Mueller et al. 1989) and decreases in response to treatment with TGF $\beta 1$.

Concordant with ligand expression, EGF receptors are distributed throughout the anterior pituitary. In pituitaries derived from 2-month-old male mice, $E G F R$ mRNA was detected in $47 \%$ of anterior pituitary cells by ISH, while no expression was found in intermediate and posterior pituitary cells (Honda et al. 2000). About half of all rat anterior pituitary cells express EGFR as detected by IHC (Mouihate \& Lestage 1995a) though when using an antibody directed against the intracellular domain of the rat EGFR, positive staining is found in only $\sim 15 \%$ of all pituitary cells (Fan \& Childs 1995). In normal human pituitary glands, EGFR protein expression is demonstrated in all cell types with both antibodies directed against the intra- and extracellular receptor domains (Theodoropoulou et al. 2004). EGFR protein expression was also detected by WB $(170 \mathrm{kDa}), E G F R$ mRNA by RT-PCR in normal pituitaries, and weak EGFR positivity by ISH using microarrays (Onguru et al. 2004).

Approximately $64 \%$ of pituitary adenomas express EGFR mRNA and/or protein, in $66 \%$ of all nonfunctioning adenomas and $62 \%$ of functioning adenomas with higher expression levels observed in tumors with a more aggressive phenotype (LeRiche et al. 1996, Jaffrain-Rea et al. 1998).

\section{ErbB2 receptor}

Positive pituitary ErbB2 immunostaining by ICC with the use of a monoclonal antibody to the cytoplasmic domain of ErbB2 was observed in normal rat and human pituitary cells (Chaidarun et al. 1994a, Nose-Alberti et al. 1998, Martin-Lacave \& Utrilla 2000). IHC with an antibody to the internal ErbB2 domain shows a granular and cytoplasmic ErbB2 staining pattern in only a few scattered cells, though mRNA transcript signals are detected in the normal pituitaries tested (Ezzat et al. 1997).

ErbB2 receptor expression is found overall in $31 \%$ of all pituitary tumors, in $43 \%$ of non-functioning pituitary adenomas (Birman et al. 1987, Chaidarun et al. 1994a, Kontogeorgos et al. 1996, LeRiche et al. 1996, Jaffrain-Rea et al. 1998, Onguru et al. 2004, Theodoropoulou et al. 2004) and in $24 \%$ of functioning adenomas (Chaidarun et al. 1994a, Ezzat et al. 1997, Nose-Alberti et al. 1998, Ferreira et al. 2005, Botelho et al. 2006, Vlotides et al. 2009). Positive cytoplasmic ErbB2 staining was observed in a variable number of cells in $40 \%$ of invasive pituitary adenomas $(n=103)$, while only $1.2 \%$ of the non-invasive tumors $(n=241)$ expressed this protein $(P<0.001$; Nose-Alberti et al. 1998).

\section{ErbB3/4 ligands and receptors}

HRG, also called neuregulin (NRG), neu differentiation factor, glial growth factor (GGF), and acetylcholine receptor-inducing activity, is a soluble secreted growth factor which serves as a ligand for ErbB3 and ErbB4 (Breuleux 2007). HRG-1 type II encodes GGF (Breuleux 2007), which was originally identified from bovine pituitary extracts (Brockes et al. 1980, Lemke \& Brockes 1984). However, the cellular source and function of HRG, as well as that of other ErbB receptor ligands such as HB-EGF, AR, ER, and betacellulin in the normal anterior pituitary are not known.

ErbB3 normal pituitary gland expression has not been examined. However, the fourth member of the EGFR family ErbB4 is expressed at relatively high levels in the normal pituitary gland, as determined by RT-PCR (Plowman et al. 1993); the cellular source and function of pituitary ErbB4 expression is not known.

\section{Corticotroph cells}

\section{EGFR ligands and receptor}

EGFR ligand expression has been detected in normal pituitary corticotroph cells by some (Kontogeorgos et al. 1996) though not confirmed by all (Kasselberg et al. 1985, Chaidarun et al. 1994a). Though TGF $\alpha$ mRNA expression has not been found in corticotroph cells (Fan \& Childs 1995), TGF $\alpha$ induces proliferation of corticotrophs via enhanced BrdU uptake (Oomizu et al. 2000, Sharma et al. 2003).

EGFR expression localizes to normal human corticotrophs on autopsy specimens (Kontogeorgos et al. 1996) using IHC with antibodies directed against both the intra- and extracellular domains of EGFR (Theodoropoulou et al. 2004).

EGFR ligands have a functional role in corticotrophs and may regulate HPA-axis activation at several levels as observed in animal models. EGF may regulate ACTH release through hypothalamic CRH induction (Luger et al. 1988) shown through EGF infusions in near-term ovine fetuses that led to increased circulating ACTH concentrations (with a similar potency to synthetic CRF) without affecting circulating CRF, AVP, or catecholamine levels (Polk et al. 1987). EGF may also have a direct effect on corticotrophs or participate in paracrine-pituitary interactions, as seen when EGF induced POMC mRNA expression, ACTH secretion and corticotroph cell proliferation in 
populations of mixed and enriched rat corticotrophs obtained by counterflow centrifugation (Childs et al. 1991, 1995). Treatment of mouse pituitary primary cultures with EGF for 5 days induced corticotroph replication (Honda et al. 2000). Furthermore, TGF $\alpha$ also exerts mitogenic effects on mouse corticotrophs and appears to be involved in EGFR-dependent estrogen-mediated induction of corticotroph cell proliferation (Oomizu et al. 2000). TGF $\alpha$ mRNA and protein is also expressed in corticotroph adenomas (Ezzat et al. 1995).

EGFR ligands and receptor are observed in normal corticotrophs and also in adenomatous tissue. In one series, EGF expression by IHC was reported in $38 \%$ (7/19) of ACTH-secreting tumors adenomas, with higher expression in invasive adenomas, and in $2 / 2$ carcinomas, while metastases exhibited a higher EGF content compared with the carcinoma itself (Lubke et al. 1995). Other groups reported positive EGF expression rates as high as $80 \%$ in corticotroph adenomas (Kontogeorgos et al. 1996) and detected EGF mRNA by RT-PCR and protein in 4/5 corticotroph adenomas (LeRiche et al. 1996). However, measurable quantities of EGF were not detected by ELISA of the medium of cultured adenomas (LeRiche et al. 1996).

With the exception of one series which used an antibody targeting only the extracellular domain (Chaidarun et al. 1994a), EGFR expression in corticotroph adenomas has consistently been demonstrated, with a reported overall positive rate of $75 \%$ of 77 corticotroph tumors tested, by both IHC and ISH techniques and variable antibodies (Kontogeorgos et al. 1996, Jaffrain-Rea et al. 1998, Onguru et al. 2004, Theodoropoulou et al. 2004). Using an antibody targeting the intracellular EGFR domain in 102 pituitary adenomas, strongly positive EGFR immunoreactivity was detected in corticotroph adenomas with weaker staining noted in other functioning and nonfunctioning adenomas (Theodoropoulou et al. 2004). Overall, ACTH-secreting adenomas exhibit significantly higher number of EGFR immunoreactive cells, and a higher rate of phospho-EGFR (Tyr 922), the active form of EGFR (Theodoropoulou et al. 2004).

In contrast to the known functional effects of EGFR and its ligands on normal corticotrophs, little is known of the functional role of this pathway in corticotroph tumors. In AtT20 cells, a mouse corticotroph tumor cell line, EGF-stimulated cell proliferation, but this did not translate to increased ACTH secretion (van Wijk et al. 1995). Furthermore, neither EGFR nor ErbB2 receptor expression were detected inAtT20 cells, nor were inhibitory effects on AtT20 cell proliferation observed by treatment with the EGFR inhibitor gefitinib (Vlotides et al. 2008).

\section{ErbB2 receptor}

ErbB2 receptors localize to normal corticotrophs on ICC (Chaidarun et al. 1994a) but are not as abundantly detected as EGFR in corticotroph adenomas, with overall rate of $13 \%$ tumors positive in several series (Chaidarun et al. 1994a, Ezzat et al. 1997, NoseAlberti et al. 1998). However, a report of one pituitary ACTH-producing carcinoma exhibited granular cytoplasmic and membrane staining in $20 \%$ of the cells of the surgery and $30 \%$ of autopsy material, while liver metastases showed positive ErbB2 staining in the cytoplasm and membrane in $80 \%$ of cells (NoseAlberti et al. 1998).

\section{ErbB3/4 ligands and receptors}

To date, ErbB3 and ErbB4 have not been explored in normal or tumoral corticotrophs.

\section{Discussion}

Of the ErbB receptor family, EGFR and its ligands play the dominant role in both normal and adenomatous corticotrophs. Expression studies confirm localization of EGFR and its ligands, and functional studies demonstrate a role of EGF and EGFR in corticotroph proliferation and hormone secretion both in a direct and paracrine fashion. Further studies remain to determine the role of ErbB receptors in corticotroph tumor development and behavior.

\section{Gonadotroph cells}

\section{EGFR ligands and receptor}

Double immunostaining for EGF protein with pituitary hormones performed by two different groups identified EGF-positive cells in gonadotrophs and thyrotrophs (Kasselberg et al. 1985, Chaidarun et al. 1994b) while ISHIC coupled with immunostaining for pituitary hormones revealed $E G F$ mRNA localization only in LH and FSH cells (Fan \& Childs 1995). In pituitary specimens derived from immature female rats, most EGF-secreting cells were identified as LH-positive gonadotrophs $(\sim 72 \%)$, and EGF secretion was enhanced by LHRH treatment (Mouihate et al. 1996a). Secreted TGF $\alpha$ from untransformed bovine anterior pituitary cells in culture (Kobrin et al. 1986, Samsoondar et al. 1986) and subsequent expression analysis by IHC did not reveal TGF $\alpha$ protein expression in gonadotrophs (Kobrin et al. 1986) though 
$T G F \alpha$ mRNA was positive in rat gonadotrophs (Fan \& Childs 1995). EGF receptor expression is abundant in normal gonadotrophs with both extra- and intracellular targeted antibodies on ICC (Fan \& Childs 1995, Theodoropoulou et al. 2004). Approximately $45 \%$ of pituitary cells from metestrous rats demonstrated positive EGFR labeling, though expression levels gradually declined in later stages (to $25 \%$ by proestrus; Armstrong \& Childs 1997a).

A number of studies have investigated the functional effects of the EGFR pathways in normal gonadotrophs both at the level of the hypothalamus and pituitary. In primary pituitary cultures, EGF enhances LH release (Przylipiak et al. 1988) while in turn LHRH stimulation further increases EGF secretion, in a positive feedback mechanism. Moreover, EGF stimulates gonadotroph proliferation, increases the percentage of gonadotroph cells in $\mathrm{S}$ phase, as well as stimulates immediate early genes (i.e. $c$-fos; Childs \& Unabia 2001).

Further evidence of the direct effects of EGFR and its ligands on gonadotrophs is demonstrated by studies in menstrual changes in animal models. At the initial proestrous stage, EGFR expression is at its highest level in gonadotrophs, concurrent with increasing $L H \beta$ mRNA in LH cells as well as higher levels in FSH $\beta$ antigen-bearing cells (Armstrong \& Childs 1997a, Childs \& Armstrong 2001). EGF further stimulates the $\mathrm{GnRH}$ receptor as well as its own cognate receptor in gonadotroph cells, which is under negative feedback from the elevated estrogen levels in proestrous stage (Armstrong \& Childs 1997b, Childs \& Unabia 2001). In the estrous stage, GnRH then stimulates EGFR expression in FSH cells (Childs \& Armstrong 2001). Next, in metestrous, pituitary EGFR expression undergoes cyclic change with most EGF responsive cells evident during metestrous, leading to the lowest levels of EGFR in the cycle (Armstrong \& Childs 1997a). However, estradiol treatment of metestrous cultured anterior pituitary cells can increase the size and percentage of EGF plaque-forming cells to levels seen in proestrous cultures (Mouihate \& Lestage 1995b). EGF can also stimulate GnRH receptors during this stage (Childs \& Armstrong 2001). Finally, in diestrous, EGFR again increases together with $L H \beta$ mRNA in developing LH gonadotroph cells (Armstrong \& Childs 1997a). In summary, these studies suggest that EGF acts as an autocrine or paracrine factor to maintain and develop gonadotrophs and functions in preparation for the LH surge (Childs \& Armstrong 2001).

EGF also has an indirect regulatory effect on gonadotrophs through the hypothalamus. In cultured adenohypophyseal cells, EGF stimulated GnRH binding and potentiated $\mathrm{LH}$ response to $\mathrm{GnRH}$ but did not directly increase LH secretion (Leblanc et al. 1997). Early study perifused pituitaries of cycling female rats with EGF that led to LH release from hypothalamo-pituitary pairs but not from the pituitary itself. On the other hand, infusion with both EGF and estradiol did lead to significant LH release, suggesting that EGF regulated pituitary gonadotropin secretion by a direct effect on the hypothalamus and indirectly at the pituitary by increasing pituitary responsiveness to estradiol (Miyake et al. 1985). Furthermore, TGF $\alpha$ is a physiological ligand for $\mathrm{LHRH}$ via the EGF/TGF $\alpha$ receptor in the developing female rat hypothalamus, as shown by the dose-related increase in LHRH when stimulated with both EGF and TGF $\alpha$ while blockade of EGF alone did not block LHRH release (Ojeda et al. 1990).

EGF receptors are modulated at the level of the hypothalamus as well. Src and Pyk2 potentiate transactivation required for GnRH-induced ERK1/2 phosphorylation in hypothalamic GnRH neurons (GT1-7; Shah et al. 2003b). GnRH-induced ERK1/2 phosphorylation caused by EGFR transactivation limited to GT1-7 neuronal cells and attenuated by an EGFR kinase inhibitor (Shah et al. 2003a). Looking at the GnRH development through menstrual cyclic changes, EGFR mRNA increases in medial basal hypothalamus at the initiation of puberty, decreases in the first morning of proestrous, and increases during the afternoon, at the time of the gonadotropin surge, concurrent with changes in EGFR protein levels (Ma et al. 1994). EGFR-induced signaling in hypothalamic astroglia has been shown to be crucial for production of glial-derived molecules that stimulate GnRH neurons to release GnRH (Ma et al. 1997). Disruption of EGFR signaling in astroglia of female mice resulted in irregular estrous cycles and decreased LH secretion (Li et al. 2003).

In vivo models have further confirmed that EGF inhibits the hypothalamic pulse generator for $\mathrm{LH}$ secretion while inhibiting follicular estradiol production. In rams treated with subcutaneous EGF, mean plasma LH, FSH, and testosterone were significantly reduced for $48 \mathrm{~h}$ compared with a control group. When both EGF-treated rams and the controls were then injected with LHRH, LH, and testosterone levels increased though the levels did not differ between the groups (Brown et al. 1989). On the other hand, EGF infusion into merino ovariectomized ewes did lead to reduced frequency of pulsatile LH secretion by inhibiting LHRH release from the hypothalamus (Radford et al. 1987). Infusion of EGF during luteal 
phase of adult merino ewes had no effect on progesterone levels while infusion during the follicular phase led to suppression of estradiol rise. LH pulse amplitude was increased while pulse frequency decreased (Shaw et al. 1985).

Together, these studies suggest that EGFR and its ligands are involved in development and maintenance of gonadotroph function at different levels of the hypothalamic-pituitary-gonadal axis.

Fewer data are available on EGFR expression and function in gonadotroph adenomas. Overall, $75 \%$ of the 56 non-functioning adenomas tested express EGF either by IHC or by RT-PCR with rates varying between 10 and $100 \%$ in different series (Chaidarun et al. 1994a, Kontogeorgos et al. 1996, LeRiche et al. 1996, Otsuka et al. 1999). In addition, TGF $\alpha$ mRNA and protein are detected in non-functioning adenomas (Driman et al. 1992, Ezzat et al. 1995). EGFR mRNA and protein expression has been characterized in 379 non-functioning adenomas, with overall positive rate of $66 \%$ though each study had rates ranging from 0 to $100 \%$ of tumors tested, depending on the technique (Birman et al. 1987, Chaidarun et al. 1994a, Kontogeorgos et al. 1996, LeRiche et al. 1996, Jaffrain-Rea et al. 1998, Onguru et al. 2004, Theodoropoulou et al. 2004). EGF binding sites are detected in gonadotroph macroadenomas, with binding higher in invasive adenomas and especially in those invading the sphenoid sinus, independent of other markers (Jaffrain-Rea et al. 1998), suggesting that EGF binding may be an additional marker of pituitary tumor aggression.

The functional role of EGFR in non-functioning adenomas has been explored in a limited basis. An early study tested growth factors derived from tumor-conditioned media obtained from 23 cultured human NFAs. Neutralizing antibodies directed against EGF reduced the growth promoting activity of tumorconditioned media (Renner et al. 1993). In primary cultures of NFAs expressing $\alpha$-subunit mRNA, addition of EGF led to increased ${ }^{3} \mathrm{H}$-thymidine uptake and cell number. EGFR mRNA level was enhanced fourfold by EGF while $\alpha$-subunit mRNA was reduced by EGF (Chaidarun et al. 1994a).

In alphaT3-1 cells, a gonadotroph tumor line, GnRH challenge led to ERK activation, an effect that was abrogated by an EGFR TKI (Grosse et al. 2000). Crosstalk between GnRH and EGFR may occur through gelatinases of the MMP family. Administration of MMP inhibitors in alphaT3-1 cells abolished transactivation of EGFR by GnRH (Roelle et al. 2003).

\section{ErbB2 receptor}

In contrast to the extensive research on the EGFR pathways, little is known on the expression and function of ErbB2 receptors in normal gonadotrophs, with only one study reporting positive ErbB2 expression in gonadotroph cells (Chaidarun et al. 1994a). ErbB2 expression in non-functioning adenomas ranges from 0 to $100 \%$, with overall positive rate of $43 \%$ in 174 tumors tested (Chaidarun et al. 1994a, Ezzat et al. 1997, Nose-Alberti et al. 1998, Ferreira et al. 2005). However, direct sequencing of codon 659 within a set of tumors revealed no point mutations, and differential PCR did not show the presence of DNA amplification (Ezzat et al. 1997). Positive cytoplasmic ErbB2 staining was observed in a variable number of cells in $40 \%$ of invasive pituitary adenomas $(n=103)$, while only $1.2 \%$ of the non-invasive tumors $(n=241)$ expressed this protein $(P<0.001)$; however, no particular immunohistological type preferentially expressed the protein in this study (Nose-Alberti et al. 1998). In two pituitary gonadotroph cell carcinomas, ErbB2 immunoreactivity and low level ErbB2 gene amplification were observed in the metastases of the first case while the second case did not display ErbB2 overexpression or gene amplification in the sellar component or the metastases of the tumor (Roncaroli et al. 2003).

\section{Discussion}

Similar to corticotroph cells, EGFR and its ligands are the dominant ErbB receptor in normal and adenomatous gonadotrophs. It is evident that EGFR is a regulator of gonadotroph development, confirmed in the menstrual cycle studies, both at the hypothalamic and pituitary level. In non-functioning adenomas, EGFR expression may be associated with more invasive phenotypes, but it remains to be determined how this is mediated and whether it is of clinical import.

\section{Lacto-somatotroph cells}

\section{EGFR ligands and receptor}

EGFR and its ligands are detected in normal lactosomatotroph cells in multiple animal models. In rat anterior pituitary cells, EGF localized to $27 \%$ of PRLpositive and $20 \%$ of $\mathrm{GH}$-positive cells, by both reverse hemolytic plaque assay and IHC techniques (Mouihate \& Lestage 1995b) while others did not confirm these findings on routine immunostaining (Kasselberg et al. 1985, Chaidarun et al. 1994a). However, EGF mRNA 
is detected using ISH (Fan \& Childs 1995). TGF $\alpha$ mRNA expression has been detected in mouse and rat anterior pituitary cell cultures by RT-PCR, ISH, and IHC, particularly in somatotrophs as well as some lactotrophs (Fan \& Childs 1995, Sharma et al. 2003). Identification of secreted TGF $\alpha$ from untransformed bovine anterior pituitary cells in culture (Kobrin et al. 1986, Samsoondar et al. 1986) and subsequent expression analysis by IHC revealed TGF $\alpha$ expression in lactotrophs and somatotrophs (Kobrin et al. 1987). In human normal pituitary tissue, immunoreactive $\mathrm{TGF} \alpha$ is present in all adenohypophyseal cell types, with predominant reactivity in the lateral wings (Driman et al. 1992), and one group observed TGF $\alpha$ co-localization in GH- but not PRL-immunopositive cells (Finley et al. 1994). Finally, receptors to EGF have been detected on binding assays and IHC in somatotrophs and lactotrophs (Chabot et al. 1986, Fan \& Childs 1995, Theodoropoulou et al. 2004).

EGFR and its ligands are expressed in lactosomatotroph cells and also have a functional role in PRL regulation at both gene and protein levels, leading to changes in prolactin transcription and synthesis (Murdoch et al. 1982), pituitary proliferation, and hormonal secretion (Mouihate \& Lestage 1995a,b, Mouihate et al. 1996a,b); thus far, EGF has been shown to have little effect on GH regulation (Ikeda et al. 1984, Lewis et al. 2002).

Evidence for stimulation of lactotroph proliferation by EGFR ligands is demonstrated from mouse models. Treatment of mouse pituitary primary cultures (serumfree medium) with EGF ( 1 and $10 \mathrm{ng} / \mathrm{ml}$ ) for 5 days stimulated BrdU labeling approximately threefold in lactotrophs, while no effect was observed in other subsets of pituitary cells (Honda et al. 2000). Treatment with TGF $\alpha(0.1$ and $1 \mathrm{ng} / \mathrm{ml})$ also induced BrdU labeling in anterior pituitary mouse cells (Oomizu et al. 2000, Takahashi et al. 2002, Sharma et al. 2003). Interestingly, estrogen $\left(10^{-9} \mathrm{M} ; 5\right.$ days)induced lactotroph proliferation (threefold) as well as expression of $T G F \alpha$ and EGFR mRNA, while estrogen-mediated induction of cell proliferation was blocked by the EGFR inhibitor RG-13022 or the TGF $\alpha$ antisense oligodeoxynucleotide, suggesting that TGFa mediates stimulatory effects of estrogen on lactotroph cell proliferation (Oomizu et al. 2000, Takahashi et al. 2002, Sharma et al. 2003).

Furthermore, EGF enhances PRL secretion, up to $240 \%$ in neonatal lactotrophs (Felix et al. 1995). In cultured pituitaries derived from vehicle- and estrogen-treated rats, EGF increased PRL response to TRH in vehicle-treated rats while decreasing PRL response in estrogen-treated rats. EGF treatment also increased the dopaminergic inhibition in estrogentreated rats and blocked the post-dopamine prolactin rebound seen in vehicle-treated rats (Spuch et al. 2006). These reports suggest that EGF effects on lactotrophs are estrogen dependent.

The effects of EGFR ligands can be blocked at the level of the receptor in normal lacto-somatotrophs. Using a mutant EGFR lacking the intracellular tyrosine kinase domain (EGFR-tr), EGFR signaling was blocked in cultured cells. EGFR-tr was expressed in transgenic mice, under control of the PRL or GH promoters respectively. EGFR-tr overexpression in GH-producing cells during embryogenesis resulted in dwarf mice with pituitary hypoplasia with blockade of lactotroph and somatotroph development. Overexpression during the postnatal period did not lead to a distinct phenotype which may implicate an EGFR role in differentiation of lacto-somatotrophs in early pituitary organogenesis but not in postembryotic periods (Roh et al. 2001).

In contrast to other pituitary tumors as described above, much work has been done to understand the EGFR pathway in GH- and PRL-secreting adenomas. First, EGFR and its ligands have been shown to be expressed in the majority of studies. By either IHC or RT-PCR techniques, EGF has been detected in 50\% of $\mathrm{GH}$-secreting adenomas, $74 \%$ of prolactinomas, and $41 \%$ of mixed GH/PRL adenomas tested (Chaidarun et al. 1994a, Kontogeorgos et al. 1996, LeRiche et al. 1996, Muller et al. 1999, Otsuka et al. 1999). Level of invasion does not seem to affect EGF expression levels in bi- and plurihormonal adenomas of patients with acromegaly, though expression levels were higher in non-invasive GH-PRL-mixed cell adenomas compared with non-invasive plurihormonal adenomas (Muller et al. 1999). In addition, TGF $\alpha$ expression has been confirmed with both IHC and RT-PCR in GHand PRL-secreting adenomas (Driman et al. 1992, Ezzat et al. 1995). Finally, over half of GH, PRL, and GH/PRL adenomas express EGFR, as confirmed on multiple techniques including ICC, IHC, binding assays, RT-PCR, and ISH (Kontogeorgos et al. 1996, Jaffrain-Rea et al. 1998, Onguru et al. 2004, Theodoropoulou et al. 2004).

The availability of lacto-somatotroph tumor cell lines (GH3 and GH4 cell lines) has made it possible to study the function of EGFR and its ligands in pituitary tumorigenesis. EGF has a number of effects on cell proliferation and morphology in lacto-somatotroph tumor cells. While some studies demonstrate that EGF decreased cell proliferation in GH3/GH4 cells (Schonbrunn et al. 1980, Hapgood et al. 1983), others found that cell proliferation increased with EGF 
treatment (Murdoch et al. 1982, Chen et al. 2009) and is further enhanced by estrogen (Chen et al. 2009). Gefitinib, an EGFR kinase inhibitor, dose-dependently decreased cell proliferation in GH3 cells (Vlotides et al. 2008). However, treatment of $\mathrm{GH} 3$ cells with another EGFR kinase inhibitor, AG1478, did not block estrogen effects on cell proliferation, suggesting that estrogen receptor function is not dependent on EGFR (Chen et al. 2009).

EGF signaling alters lacto-somatotroph morphology, leading to elongation of cells (Johnson et al. 1980, Hapgood et al. 1983). A monoclonal antibody to EGF-induced synthesis of PRL and morphological changes in GH3 cells (Hapgood et al. 1983). Similar to effects of TRH, chronic EGF treatment $(>24 \mathrm{~h})$ of $\mathrm{GH} 4$ cells decreases cell proliferation by $30-40 \%$ with change in cellular morphology from spherical shape to elongated flattened shape and 40-60\% increase in cell volume (Schonbrunn et al. 1980). These effects may be blocked by a MEK1 inhibitor, implicating the MAPK pathway (Lewis et al. 2002).

In addition to affecting cell proliferation and morphology in GH3/4 cells, EGF upregulates PRL gene expression (Murdoch et al. 1982, Chen et al. 2009) though Pit1 and D2 receptor mRNA are not increased (Zhang et al. 1993). EGF regulation of PRL gene transcription may instead be mediated by protein kinase C (Pickett et al. 2002). EGF and TRH both induce transcription of the PRL promoter via similar cis elements (Berwaer et al. 1993) while the distal enhancer sequence of the PRL gene contains elements conferring EGF responsiveness (Day \& Maurer 1989). EGF regulates TRH receptors on pituitary GH4C1 cells and TRH responsiveness of these cells (Hinkle et al. 1991). Together, these changes lead to increased proportion of lactotrophs in GH3 cultures without affecting the proportion of GH-positive cells (Felix et al. 1995).

GH3 cells lack D2 dopamine receptors, but treatment with EGF induces expression of the endogenous D2 receptor gene, leading to a tenfold increase in $\mathrm{G}_{\mathrm{i} 3} \alpha$ subunit (Missale et al. 1991). These induced D2 receptors are functional and coupled to delayed outward K+ current (Gardette et al. 1994). In GH4C1 cells transfected with D2 receptor, EGF treatment leads to decreased coupling of D2, inhibiting cAMP-dependent responses while increasing membrane content of $\mathrm{G}_{\mathrm{i} 3}$ protein (Missale et al. 1994). These effects are independent of the Ras pathway (Pickett \& Gutierrez-Hartmann 1994).

The effects of EGFR and its ligands on gene expression translate to changes in hormone secretion.
Initially, EGF inhibits GH synthesis in GH3 cells while long-term incubation results in enhanced PRL secretion (Johnson et al. 1980, Schonbrunn et al. 1980, Hapgood et al. 1983). In GH4C1 cells, EGF dose-dependently stimulates acute PRL release with peak secretion achieved after $60 \mathrm{~s}$ (Aanestad et al. 1993). GH3 cells transfected with a PRL/luciferase reporter gene and treated with EGF had a dosedependent increase in PRL gene expression that positively correlated with PRL release. When GH3 cells were treated with EGF for $48 \mathrm{~h}$ with/without EGFR inhibitor AG1478 or ErbB2 inhibitor AG825, AG1478 blocked EGF action, confirmed by blockade of ERK1/2 that was not seen with AG825. The antiestrogen ICI 182780 and an ER $\alpha$-specific antagonist blocked EGF-induced PRL release and gene expression while an ER $\beta$ antagonist had no effect as confirmed by siRNA directed against ER $\alpha$. ERK1/2 was not affected by antiestrogens, indicating that they do not block proximal EGFR signaling events. These results demonstrate that EGF signals through EGFR activation in lactotrophs and that PRL stimulation by EGF is dependent on ER $\alpha$ and involves ERK1/2 phosphorylation (Ben-Jonathan et al. 2009).

EGF induces tyrosine phosphorylation of EGFR and ErbB2 in GH3 cells, and these effects can be blocked by gefitinib (Vlotides et al. 2008). While EGF enhances baseline and serum-induced $P R L$ mRNA and attenuates $G H$ mRNA expression in GH3 cells, treatment with gefitinib, an EGFR TKI, dosedependently attenuates serum-induced $S$ phase entry while stimulating $\mathrm{GH}$ and inhibiting $P R L$ mRNA expression and decreasing cell proliferation (Vlotides et al. 2008). To examine in vivo effects of EGFR of lacto-somatotroph tumors, GH3 cells were implanted subcutaneously in female athymic mice. Gefitinibtreated mice had a $50 \%$ decrease in tumor volume compared with 26-fold increase in tumor volume in placebo as well as a decrease in PRL levels. Tumor ERK 1/2 phosphorylation was decreased in gefitinibtreated mice, and PRL but not GH gene expression was decreased (Vlotides et al. 2008). Together, these results indicate a potential role of EGFR blockade in lacto-somatotroph tumors.

\section{ErbB2 receptor}

ErbB2 expression has been more extensively investigated in lacto-somatotroph cells than in other pituitary cell lines. In addition to detection of ErbB2 in normal lacto-somatotrophs (Chaidarun et al. 1994a), IHC with antibodies targeting intra- and extracellular domains and RT-PCR confirms ErbB2 expression in $24 \%$ of 
GH-secreting adenomas, $26 \%$ of PRL-secreting, and $32 \%$ of GH/PRL-adenomas tested (Chaidarun et al. 1994a, Ezzat et al. 1997, Nose-Alberti et al. 1998, Botelho et al. 2006, Vlotides et al. 2009). In one study, immunofluorescence staining for ErbB2 was performed in eight human PRL-secreting tumors and positive ErbB2 staining with varying intensities was observed in 7/8 tumor specimens (Vlotides et al. 2009). In a patient who initially underwent surgery for invasive but histologically benign prolactinoma (specimen from 1997) which exhibited progressive dopamine agonist resistance and recurred after four consecutive transsphenoidal pituitary surgeries (specimen from 2008, Ki-67 index of 20\%), ErbB2 mRNA expression compared by quantitative PCR analysis showed approximately fivefold increased ErbB2 mRNA expression levels in the more aggressive second specimen (Fig. 2; Vlotides et al. 2009). A more recent observation in two prolactinomas demonstrated positive nuclear and membranous EGFR staining in one tumor, and in the nucleus in a second tumor (Fig. 3; Fukuoka et al. 2011).

When GH3 cells were stably transfected with an expression vector containing a constitutively active form of ErbB2cDNA (HER2CA) which express tenfold higher HER2 protein, higher levels of phosphorylated EGFR, higher EGF-induced levels of EGFR and MAPK, and higher HRG-induced phosphorylated ErbB3 and AKT levels were observed. HER2CA cells exhibited 250-fold induction of $P R L$ mRNA and 100-fold PRL secretion with no effects on $G H$ mRNA expression and secretion. Wistar-Furth rats implanted with HER2CA transfectants also had larger tumors elevated PRL levels (Fukuoka et al. 2011).
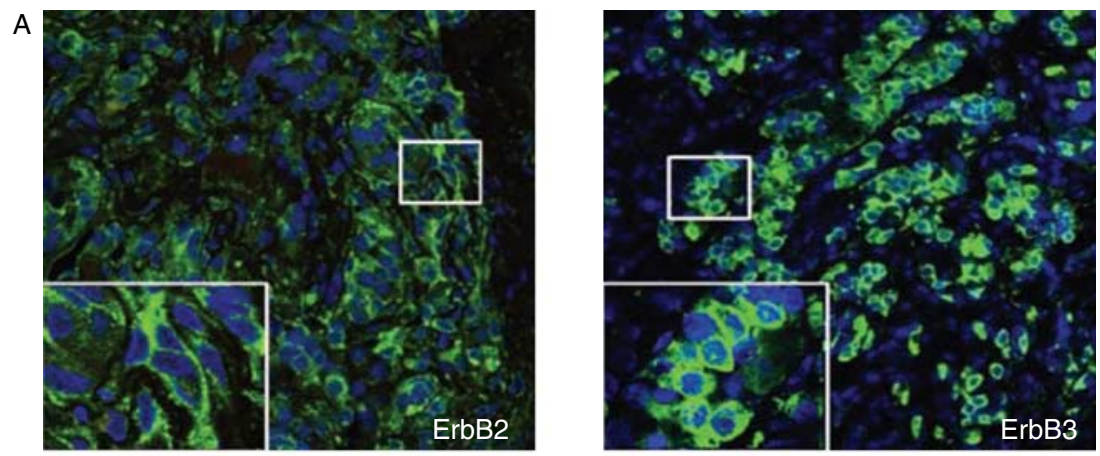

B

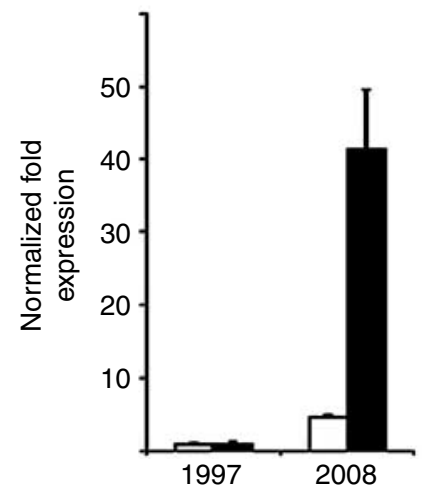

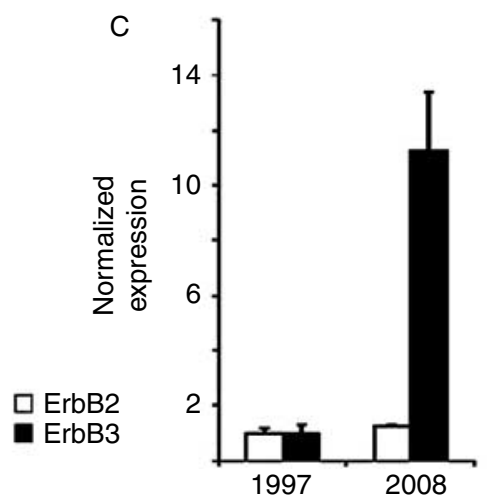

Figure 2 ErbB2 and ErbB3 expression in human prolactinomas. (A) ErbB2 and ErbB3 immunostaining in a benign human prolactinoma: fluorescent confocal microscopy images of ErbB2 (left panel) and ErbB3 (right panel) in a human PRL-secreting adenoma. ErbB receptor expression in green (Alexa 488) and nucleic acid staining (TO-PRO-3) in blue. The field size is 375 and $75 \mu \mathrm{m}$ for the insert. (B \& C) ErbB2 and ErbB3 mRNA expression in malignantly transformed prolactinoma: quantitative PCR analysis for ErbB2 and ErbB3 mRNA expression in tumor specimens derived from the same patient who initially presented with a benign prolactinoma (1997) which underwent malignant transformation (2008). (B) Internal normalization was performed with two housekeeping genes (GAPDH and TFRC) which were unchanged between the two specimens. (C) Internal normalization was performed with ten housekeeping genes (GUSB, ACTB, GAPDH, TFRC, PGK1, HPRT, PP1A, RPL13A, TBP, and B2M) (reproduced with permission from Vlotides G, Cooper O, Chen YH, Ren SG, Greenman Y \& Melmed S 2009 Heregulin regulates prolactinoma gene expression. Cancer Research 69 4209-4216 Copyright 2009, American Association for Cancer Research). Full colour version of this figure available via http://dx.doi.org/10.1530/ERC-11-0066. 


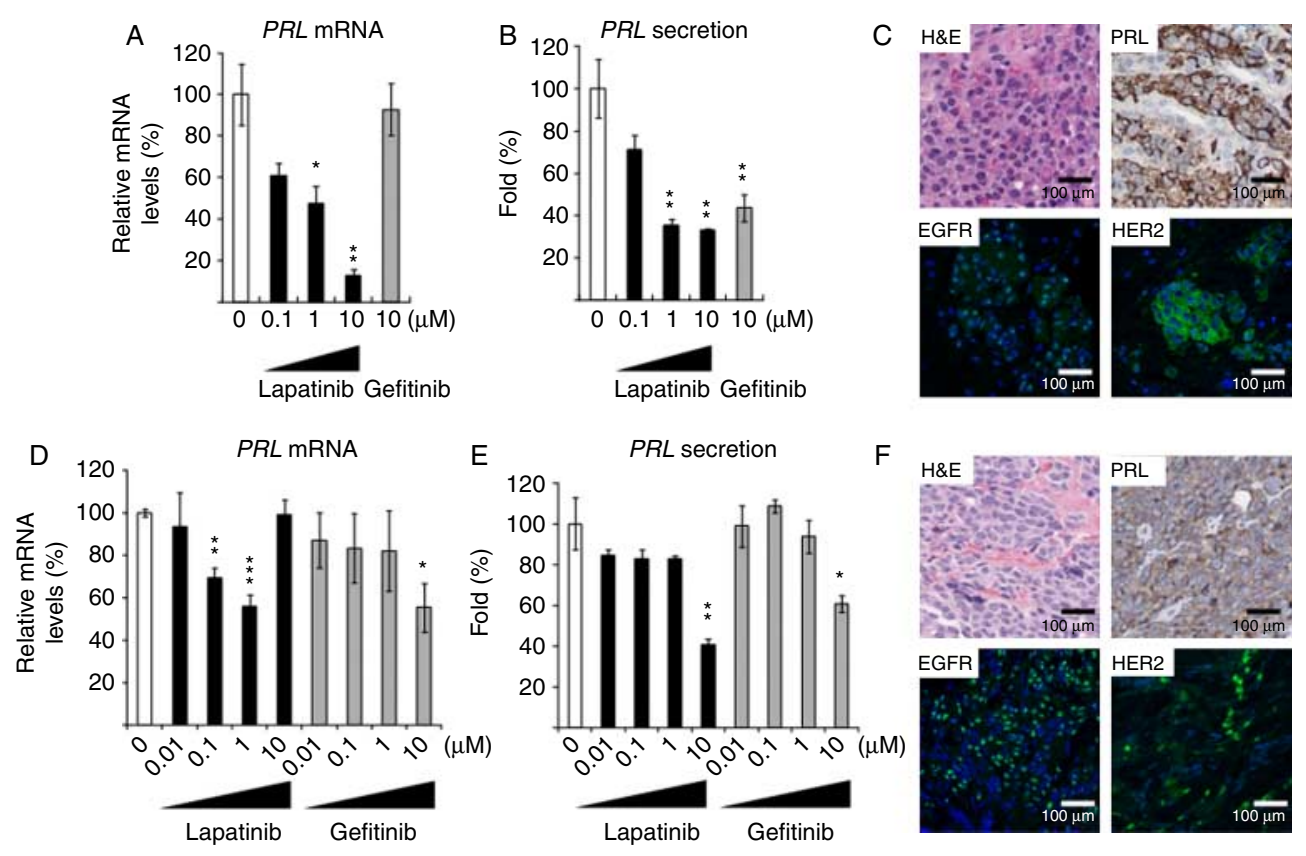

Figure 3 Lapatinib attenuates PRL secretion and mRNA expression in human prolactinoma cell cultures. (A, B, D, and E) After transsphenoidal surgery of human prolactinomas, tumor cells were cultured. Prolactinoma cells (Tumor $A$ ) were treated with lapatinib $(0.1-10 \mu \mathrm{M})$ or gefitinib $(10 \mu \mathrm{M})$ for $24 \mathrm{~h}$, and real-time PCR of PRL performed $(\mathrm{A})$. PRL levels in culture media were measured using RIA (B). H\&E and PRL staining of tumor and confocal immunocytochemistry of EGFR and HER2 (Tumor A) (C), or for Tumor B (F). Prolactinoma cells (Tumor B) were treated with lapatinib $(0.01-10 \mu \mathrm{M})$ or gefitinib $(0.01-10 \mu \mathrm{M})$ for $24 \mathrm{~h}$, and realtime PCR performed (D). PRL levels in culture media were measured using RIA (E). Prolactinoma cells (Tumor $B$ ) were treated with U0126 $(0.1-5 \mu \mathrm{M})$ for $24 \mathrm{~h}$, and real-time PCR of PRL performed $(\mathrm{F})$. Values are mean \pm s.E.M. ${ }^{*} P<0.05$, ${ }^{\star *} P<0.01$ vs control. ${ }^{* \star \star} P<0.001$ vs control (Fukuoka H, Cooper O, Mizutani J, Tong Y, Ren SG, Bannykh S \& Melmed S 2011 HER2/ErbB2 receptor signaling in rat and human prolactinoma cells: strategy for targeted prolactinoma therapy. Molecular Endocrinology 25 92-103) Copyright 2011, Endocrine Society. Full colour version of this figure available via http://dx.doi.org/10.1530/ERC-11-0066.

\section{ErbB3/4 ligands and receptor}

Staining for ErbB3 receptor was reported in 4/8 human PRL-secreting tumors (three adenomas and one carcinoma) with a $\mathrm{Ki}-67$ index of $\geq 4 \%$. ErbB3 mRNA expression compared by quantitative PCR analysis of two tumor specimens derived from a patient with progressive aggressive features showed $\sim 41$-fold increased ErbB3 mRNA expression levels in the more aggressive specimen (Fig. 2), suggesting a role for ErbB3 in malignant transformation of pituitary prolactinomas (Vlotides et al. 2009).

HRG, the ligand for ErbB3 and erbB4, did not stimulate PRL secretion in non-tumorous mixed primary rat pituitary cultures from female WistarFurth rats. However, HRG induced rapid ErbB2 and ErbB3 tyrosine phosphorylation in GH4 cells, leading to increasing $P R L$ mRNA expression and secretion while failing to induce $\mathrm{GH}$ secretion and cell proliferation. This was associated with formation of ErbB2/ErbB3 heterodimers, confirmed by immunoprecipitation. Pretreatment with gefitinib dose-dependently suppressed receptor activation and signaling as well as prevented HRG-induced ErbB2/ErbB3 heterodimerization. Using siRNA to downregulate ErbB receptor members, there was a $60 \%$ reduction of ErbB2 and ErbB3 expression in GH4 cells, associated with decrease of total tyrosine phosphorylation and $P R L$ mRNA and secretion in response to HRG, with no effect on GH. Suppression of MAPK1 by siRNA attenuated HRG-induced ERK phosphorylation, PRL mRNA, and PRL secretion, indicating that HRG mediates PRL through ERK signaling. These findings demonstrate the specificity and requirement of ErbB2 and ErbB3 for HRGmediated PRL induction (Vlotides et al. 2009).

\section{Discussion}

ErbB receptors and ligands are expressed in normal lacto-somatotroph cells and participate in PRL regulation at both gene and protein levels, leading to changes in prolactin transcription and synthesis. Lacto-somatotroph derived tumors express ErbB receptors and ligands, and manipulation of this system 
has multiple effects at the levels of gene, protein, and structure of these tumors.

\section{Therapeutic implications}

Knowledge of the role of ErbB family in malignant transformation has led to development of a class of therapeutics designed to interfere with this mechanism, including monoclonal antibodies targeting the extracellular domains, and TKIs. Application of these treatments has begun in cellular and animal models of pituitary tumors.

For instance, treatment of GH3 cells with increasing concentrations of gefitinib decreased cell proliferation and PRL mRNA expression. When GH3 cells were pretreated with gefitinib before EGF induction, the lactotroph phenotype was reversed and EGF-induced tyrosine phosphorylation of EGFR and EGF induced p185 ${ }^{\text {cneu }}$ activation blocked along with the ERK downstream signaling pathways. Gefitinib treatment of mice with GH3 induced lacto-somatotroph tumors decreased tumor volume and PRL levels by $50 \%$ compared with a 26-fold increase in vehicle-treated mice (Vlotides et al. 2008). Pretreatment of GH4C1 cells with gefitinib suppressed HRG-induced ErbB receptor activation and signaling and prevented p185 ${ }^{\text {cneu }}$ and ErbB3 heterodimerization and PRL secretion (Vlotides et al. 2009).

In stable HER2CA GH3 transfectants, lapatinib, a dual EGFR/Her2 kinase inhibitor, suppressed EGFinduced Her2 and MAPK phosphorylation as well as intracellular PRL levels to lower levels than gefitinib while $G H$ mRNA were unaffected. Lapatinib-treated cells had $40 \%$ lower PRL secretion, cell proliferation, and colony formation. Rats implanted with HER2CA cells and treated with lapatinib exhibited smaller tumor volumes and suppressed PRL levels. In another model, Fischer rats treated with $17-\beta$-estradiol developed prolactinomas and subsequently treated with lapatinib that suppressed tumor weight and PRL levels (Fukuoka et al. 2011). Finally, tumor tissue from surgically resected human prolactinomas in primary culture were treated with lapatinib which suppressed PRL mRNA $\sim 90 \%$ and PRL secretion $\sim 70 \%$ (Fig. 3; Fukuoka et al. 2011). These experiments show the efficacy of TKIs in reducing experimental pituitary tumor size and functionality.

Members of the ErbB family play an increasingly recognized role in pituitary development and tumorigenesis. Targeted ErbB therapeutics may prove effective as alternative or adjunctive medical therapy for pituitary tumors.

\section{Declaration of interest}

The authors declare that there is no conflict of interest that could be perceived as prejudicing the impartiality of the research reported. M I Greene is the inventor of patents dealing with therapy of ErbB tumors, and these are owned by the University of Pennsylvania.

\section{Funding}

This study was supported by a scholarship from the Deutsche Forschungsgemeinschaft (VL 55/1-1) and by NIH grants CA 075979 (S Melmed), and K23DK085148 (O Cooper).

\section{References}

Aanestad M, Røtnes JS, Torjesen PA, Haug E, Sand O \& Bjøro T 1993 Epidermal growth factor stimulates the prolactin synthesis and secretion in rat pituitary cells in culture (GH4C1 cells) by increasing the intracellular concentration of free calcium. Acta Endocrinologica $\mathbf{1 2 8}$ 361-366. (doi:10.1530/acta.0.1280361)

Armstrong J \& Childs GV 1997a Changes in expression of epidermal growth factor receptors by anterior pituitary cells during the estrous cycle: cyclic expression by gonadotropes. Endocrinology 138 1903-1908. (doi:10. 1210/en.138.5.1903)

Armstrong JL \& Childs GV $1997 b$ Regulation of expression of epidermal growth factor receptors in gonadotropes by epidermal growth factor and estradiol: studies in cycling female rats. Endocrinology 138 5434-5441. (doi:10.1210/ en.138.12.5434)

Ben-Jonathan N, Chen S, Dunckley JA, LaPensee C \& Kansra S 2009 Estrogen receptor-alpha mediates the epidermal growth factor-stimulated prolactin expression and release in lactotrophs. Endocrinology 150 795-802. (doi:10.1210/en.2008-0756)

Berwaer M, Peers B, Nalda AM, Monget P, Davis JR, Belayew A \& Martial JA 1993 Thyrotropin-releasing hormone and epidermal growth factor induce human prolactin expression via identical multiple cis elements. Molecular and Cellular Endocrinology 92 1-7. (doi:10. 1016/0303-7207(93)90068-U)

Birman P, Michard M, Li JY, Peillon F \& Bression D 1987 Epidermal growth factor-binding sites, present in normal human and rat pituitaries, are absent in human pituitary adenomas. Journal of Clinical Endocrinology and Metabolism 65 275-281. (doi:10.1210/jcem-65-2-275)

Botelho CH, Magalhaes AV, Mello PA, Schmitt FC \& Casulari LA 2006 Expression of p53, Ki-67 and c-erb B2 in growth hormone-and/or prolactin-secreting pituitary adenomas. Arquivos de Neuro-Psiquiatria 64 60-66. (doi:10.1590/S0004-282X2006000100013)

Breuleux M 2007 Role of heregulin in human cancer. Cellular and Molecular Life Sciences 64 2358-2377. (doi:10.1007/s00018-007-7120-0) 
Brockes JP, Lemke GE \& Balzer DR Jr 1980 Purification and preliminary characterization of a glial growth factor from the bovine pituitary. Journal of Biological Chemistry 255 8374-8377.

Brown BW, Mattner PE, Panaretto BA \& Brown GH 1989 Effect of mouse epidermal growth factor on plasma concentrations of $\mathrm{LH}, \mathrm{FSH}$ and testosterone in rams. Journal of Reproduction and Fertility 87 649-655. (doi:10.1530/jrf.0.0870649)

Chabot JG, Walker P \& Pelletier G 1986 Distribution of epidermal growth factor binding sites in the adult rat anterior pituitary gland. Peptides 7 45-50. (doi:10.1016/ 0196-9781(86)90059-8)

Chaidarun SS, Eggo MC, Sheppard MC \& Stewart PM 1994a Expression of epidermal growth factor (EGF), its receptor, and related oncoprotein (erbB-2) in human pituitary tumors and response to EGF in vitro. Endocrinology 135 2012-2021. (doi:10.1210/en.135.5.2012)

Chaidarun SS, Eggo MC, Stewart PM, Barber PC \& Sheppard MC $1994 b$ Role of growth factors and estrogen as modulators of growth, differentiation, and expression of gonadotropin subunit genes in primary cultured sheep pituitary cells. Endocrinology 134 935-944. (doi:10. 1210/en.134.2.935)

Chen S, Bangaru MLY, Sneade L, Dunckley JA, BenJonathan N \& Kansra S 2009 Epidermal growth factor receptor cross-talks with ligand-occupied estrogen receptor-alpha to modulate both lactotroph proliferation and prolactin gene expression. American Journal of Physiology. Endocrinology and Metabolism 297 E331-E339. (doi:10.1152/ajpendo.00133.2009)

Childs GV \& Armstrong J 2001 Sites of epidermal growth factor synthesis and action in the pituitary: paracrine and autocrine interactions. Clinical and Experimental Pharmacology \& Physiology 28 249-252. (doi:10.1046/j. 1440-1681.2001.03423.x)

Childs GV \& Unabia G 2001 Epidermal growth factor and gonadotropin-releasing hormone stimulate proliferation of enriched population of gonadotropes. Endocrinology 142 847-853. (doi:10.1210/en.142.2.847)

Childs G, Patterson J, Unabia G, Rougeau D \& Wu P 1991 Epidermal growth factor enhances ACTH secretion and expression of POMC mRNA by corticotropes in mixed and enriched cultures. Molecular and Cellular Neurosciences 2 235-243. (doi:10.1016/1044-7431(91)90050-X)

Childs GV, Rougeau D \& Unabia G 1995 Corticotropinreleasing hormone and epidermal growth factor: mitogens for anterior pituitary corticotropes. Endocrinology 136 1595-1602. (doi:10.1210/en.136.4.1595)

Day RN \& Maurer RA 1989 The distal enhancer region of the rat prolactin gene contains elements conferring response to multiple hormones. Molecular Endocrinology 3 3-9. (doi:10.1210/mend-3-1-3)

Driman DK, Kobrin MS, Kudlow JE \& Asa SL 1992 Transforming growth factor-alpha in normal and neoplastic human endocrine tissues. Human Pathology 23 1360-1365. (doi:10.1016/0046-8177(92)90055-8)
Ezzat S, Walpola IA, Ramyar L, Smyth HS \& Asa SL 1995 Membrane-anchored expression of transforming growth factor-alpha in human pituitary adenoma cells. Journal of Clinical Endocrinology and Metabolism 80 534-539. (doi:10.1210/jc.80.2.534)

Ezzat S, Zheng L, Smyth HS \& Asa SL 1997 The c-erbB$2 /$ neu proto-oncogene in human pituitary tumours. Clinical Endocrinology 46 599-606. (doi:10.1046/j.13652265.1997.1921003.x)

Fan X \& Childs GV 1995 Epidermal growth factor and transforming growth factor-alpha messenger ribonucleic acids and their receptors in the rat anterior pituitary: localization and regulation. Endocrinology 136 2284-2293. (doi:10.1210/en.136.5.2284)

Fan X, Nagle GT, Collins TJ \& Childs GV 1995 Differential regulation of epidermal growth factor and transforming growth factor-alpha messenger ribonucleic acid in the rat anterior pituitary and hypothalamus induced by stresses. Endocrinology 136 873-880. (doi:10.1210/en.136.3.873)

Felix R, Meza U \& Cota G 1995 Induction of classical lactotropes by epidermal growth factor in rat pituitary cell cultures. Endocrinology 136 939-946. (doi:10.1210/en. 136.3.939)

Ferreira JE, de Mello PA, de Magalhaes AV, Botelho CH, Naves LA, Nose V \& Schmitt F 2005 Non-functioning pituitary adenomas: clinical features and immunohistochemistry. Arquivos de Neuro-Psiquiatria 63 1070-1078. (doi:10.1590/S0004-282X2005000600029)

Finley EL, King JS \& Ramsdell JS 1994 Human pituitary somatotropes express transforming growth factor-alpha and its receptor. Journal of Endocrinology 141 547-554. (doi:10.1677/joe.0.1410547)

Fukuoka H, Cooper O, Mizutani J, Tong Y, Ren SG, Bannykh S \& Melmed S 2011 HER2/ErbB2 receptor signaling in rat and human prolactinoma cells: strategy for targeted prolactinoma therapy. Molecular Endocrinology 25 92-103. (doi:10.1210/me.2010-0353)

Gardette R, Rasolonjanahary R, Kordon C \& Enjalbert A 1994 Epidermal growth factor treatment induces D2 dopamine receptors functionally coupled to delayed outward potassium current (IK) in $\mathrm{GH} 4 \mathrm{C} 1$ clonal anterior pituitary cells. Neuroendocrinology 59 10-19. (doi:10. 1159/000126632)

Grosse R, Roelle S, Herrlich A, Hohn J \& Gudermann T 2000 Epidermal growth factor receptor tyrosine kinase mediates Ras activation by gonadotropin-releasing hormone. Journal of Biological Chemistry 275 12251-12260. (doi:10.1074/jbc.275.16.12251)

Halper J, Parnell PG, Carter BJ, Ren P \& Scheithauer BW 1992 Presence of growth factors in human pituitary. Laboratory Investigation 66 639-645.

Hapgood J, Libermann TA, Lax I, Yarden Y, Schreiber AB, Naor Z \& Schlessinger J 1983 Monoclonal antibodies against epidermal growth factor receptor induce prolactin synthesis in cultured rat pituitary cells (GH3). PNAS 80 6451-6455. (doi:10.1073/pnas.80.21.6451) 
Hinkle PM, Shanshala ED II \& Yan ZF 1991 Epidermal growth factor decreases the concentration of thyrotropinreleasing hormone (TRH) receptors and TRH responses in pituitary GH4C1 cells. Endocrinology 129 1283-1288. (doi:10.1210/endo-129-3-1283)

Honda J, Oomizu S, Kiuchi Y, Komatsu N, Takeuchi S \& Takahashi S 2000 Identification of epidermal growth factor mRNA-expressing cells in the mouse anterior pituitary. Neuroendocrinology 71 155-162. (doi:10.1159/ 000054532)

Ikeda H, Mitsuhashi T, Kubota K, Kuzuya N \& Uchimura H 1984 Epidermal growth factor stimulates growth hormone secretion from superfused rat adenohypophyseal fragments. Endocrinology 115 556-558. (doi:10.1210/endo115-2-556)

Jaffrain-Rea ML, Petrangeli E, Lubrano C, Minniti G, Di Stefano D, Sciarra F, Frati L, Tamburrano G, Cantore G \& Gulino A 1998 Epidermal growth factor binding sites in human pituitary macroadenomas. Journal of Endocrinology 158 425-433. (doi:10.1677/joe.0.1580425)

Johnson LK, Baxter JD, Vlodavsky I \& Gospodarowicz D 1980 Epidermal growth factor and expression of specific genes: effects on cultured rat pituitary cells are dissociable from the mitogenic response. PNAS 77 394-398. (doi:10. 1073/pnas.77.1.394)

Kajikawa K, Yasui W, Sumiyoshi H, Yoshida K, Nakayama H, Ayhan A, Yokozaki H, Ito H \& Tahara E 1991 Expression of epidermal growth factor in human tissues. Immunohistochemical and biochemical analysis. Virchows Archiv. A, Pathological Anatomy and Histopathology 418 27-32. (doi:10.1007/BF01600241)

Kaltsas GA, Nomikos P, Kontogeorgos G, Buchfelder M \& Grossman AB 2005 Clinical review: diagnosis and management of pituitary carcinomas. Journal of Clinical Endocrinology and Metabolism 90 3089-3099. (doi:10. 1210/jc.2004-2231)

Kasselberg AG, Orth DN, Gray ME \& Stahlman MT 1985 Immunocytochemical localization of human epidermal growth factor/urogastrone in several human tissues. Journal of Histochemistry and Cytochemistry $\mathbf{3 3}$ 315-322. (doi:10.1177/33.4.3884705)

Kobrin MS, Samsoondar J \& Kudlow JE 1986 Alphatransforming growth factor secreted by untransformed bovine anterior pituitary cells in culture. II. Identification using a sequence-specific monoclonal antibody. Journal of Biological Chemistry 261 14414-14419.

Kobrin MS, Asa SL, Samsoondar J \& Kudlow JE 1987 Alpha-transforming growth factor in the bovine anterior pituitary gland: secretion by dispersed cells and immunohistochemical localization. Endocrinology 121 1412-1416. (doi:10.1210/endo-121-4-1412)

Kontogeorgos G, Stefaneanu L, Kovacs K \& Cheng Z 1996 Localization of epidermal growth factor (EGF) and epidermal growth factor receptor (EGFr) in human pituitary adenomas and nontumorous pituitaries: an immunocytochemical study. Endocrine Pathology 7 63-70. (doi:10.1007/BF02739916)
Leblanc P, L'Heritier A \& Kordon C 1997 Cryptic gonadotropin-releasing hormone receptors of rat pituitary cells in culture are unmasked by epidermal growth factor. Endocrinology 138 574-579. (doi:10.1210/en.138.2.574)

Lemke GE \& Brockes JP 1984 Identification and purification of glial growth factor. Journal of Neuroscience 4 75-83.

LeRiche VK, Asa SL \& Ezzat S 1996 Epidermal growth factor and its receptor (EGF-R) in human pituitary adenomas: EGF-R correlates with tumor aggressiveness. Journal of Clinical Endocrinology and Metabolism 81 656-662. (doi:10.1210/jc.81.2.656)

Lewis MD, Ham J, Rees DA, Lewis BM \& Scanlon MF 2002 Mitogen-activated protein kinase mediates epidermal growth factor-induced morphogenesis in pituitary GH3 cells. Journal of Neuroendocrinology 14 361-367. (doi:10.1046/j.0007-1331.2002.00786.x)

Li B, Yang Z, Hou J, McCracken A, Jennings MA \& Ma MYJ 2003 Compromised reproductive function in adult female mice selectively expressing mutant ErbB-1 tyrosine kinase receptors in astroglia. Molecular Endocrinology 17 2365-2376. (doi:10.1210/me.2003-0023)

Lubke D, Saeger W \& Ludecke DK 1995 Proliferation markers and EGF in ACTH-secreting adenomas and carcinomas of the pituitary. Endocrine Pathology 6 45-55. (doi:10.1007/BF02914988)

Luger A, Calogero AE, Kalogeras K, Gallucci WT, Gold PW, Loriaux DL \& Chrousos GP 1988 Interaction of epidermal growth factor with the hypothalamic-pituitaryadrenal axis: potential physiologic relevance. Journal of Clinical Endocrinology and Metabolism 66 334-337. (doi:10.1210/jcem-66-2-334)

Ma YJ, Hill DF, Junier MP, Costa ME, Felder SE \& Ojeda SR 1994 Expression of epidermal growth factor receptor changes in the hypothalamus during the onset of female puberty. Molecular and Cellular Neurosciences 5 246-262. (doi:10.1006/mcne.1994.1029)

Ma YJ, Berg-von der Emde K, Rage F, Wetsel WC \& Ojeda SR 1997 Hypothalamic astrocytes respond to transforming growth factor-alpha with the secretion of neuroactive substances that stimulate the release of luteinizing hormone-releasing hormone. Endocrinology 138 19-25. (doi:10.1210/en.138.1.19)

Martin-Lacave I \& Utrilla JC 2000 Expression of a neu/c-erbB-2-like product in neuroendocrine cells of mammals. Histology and Histopathology 15 1027-1033.

Melmed S 2003 Mechanisms for pituitary tumorigenesis: the plastic pituitary. Journal of Clinical Investigation 112 1603-1618. (doi:10.1172/JCI200320401)

Melmed S 2009 Acromegaly pathogenesis and treatment. Journal of Clinical Investigation 119 3189-3202. (doi:10. 1172/JCI39375)

Missale C, Castelletti L, Boroni F, Memo M \& Spano P 1991 Epidermal growth factor induces the functional expression of dopamine receptors in the GH3 cell line. Endocrinology 128 13-20. (doi:10.1210/endo-128-1-13)

Missale C, Boroni F, Sigala S, Castelletti L, Falardeau P, Dal Toso R, Caron MG \& Spano P 1994 Epidermal growth 
factor promotes uncoupling from adenylyl cyclase of the rat D2S receptor expressed in GH4C1 cells. Journal of Neurochemistry 62 907-915. (doi:10.1046/j.1471-4159. 1994.62030907.x)

Miyake A, Tasaka K, Otsuka S, Kohmura H, Wakimoto H \& Aono T 1985 Epidermal growth factor stimulates secretion of rat pituitary luteinizing hormone in vitro. Acta Endocrinologica 108 175-178. (doi:10.1530/acta.0. 1080175)

Mouihate A \& Lestage J $1995 a$ Epidermal growth factor: a potential paracrine and autocrine system within the pituitary. Neuroreport 6 1401-1404. (doi:10.1097/ 00001756-199507100-00010)

Mouihate A \& Lestage J $1995 b$ Estrogen increases the release of epidermal growth factor from individual pituitary cells in female rats. Journal of Endocrinology 146 495-500. (doi:10.1677/joe.0.1460495)

Mouihate A, Verrier D \& Lestage J $1996 a$ EGF release by rat gonadotroph cells: characteristics and effects of LHRH. Life Sciences 58 107-114. (doi:10.1016/00243205(95)02263-5)

Mouihate A, Verrier D \& Lestage J $1996 b$ Identification of epidermal growth factor-secreting cells in the anterior pituitary of lactating female rats. Journal of Endocrinology 148 319-324. (doi:10.1677/joe.0.1480319)

Mueller SG, Kobrin MS, Paterson AJ \& Kudlow JE 1989 Transforming growth factor-alpha expression in the anterior pituitary gland: regulation by epidermal growth factor and phorbol ester in dispersed cells. Molecular Endocrinology 3 976-983. (doi:10.1210/ mend-3-6-976)

Muller W, Saeger W, Wellhausen L, Derwahl KM, Hamacher C \& Ludecke DK 1999 Markers of function and proliferation in non-invasive and invasive bi- and plurihormonal adenomas of patients with acromegaly: an immunohistochemical study. Pathology, Research and Practice 195 595-603.

Murdoch GH, Potter E, Nicolaisen AK, Evans RM \& Rosenfeld MG 1982 Epidermal growth factor rapidly stimulates prolactin gene transcription. Nature $\mathbf{3 0 0}$ 192-194. (doi:10.1038/300192a0)

Nose-Alberti V, Mesquita MI, Martin LC \& Kayath MJ 1998 Adrenocorticotropin-producing pituitary carcinoma with expression of c-erbB-2 and high PCNA index: a comparative study with pituitary adenomas and normal pituitary tissues. Endocrine Pathology 9 53-62. (doi:10. 1007/BF02739952)

Ojeda SR, Urbanski HF, Costa ME, Hill DF \& MoholtSiebert M 1990 Involvement of transforming growth factor alpha in the release of luteinizing hormonereleasing hormone from the developing female hypothalamus. PNAS 87 9698-9702. (doi:10.1073/pnas.87.24. 9698)

Onguru O, Scheithauer BW, Kovacs K, Vidal S, Jin L, Zhang S, Ruebel KH \& Lloyd RV 2004 Analysis of epidermal growth factor receptor and activated epidermal growth factor receptor expression in pituitary adenomas and carcinomas. Modern Pathology 17 772-780. (doi:10. 1038/modpathol.3800118)

Oomizu S, Honda J, Takeuchi S, Kakeya T, Masui T \& Takahashi S 2000 Transforming growth factor-alpha stimulates proliferation of mammotrophs and corticotrophs in the mouse pituitary. Journal of Endocrinology 165 493-501. (doi:10.1677/joe.0. 1650493)

Otsuka F, Tamiya T, Yamauchi T, Ogura T, Ohmoto T \& Makino H 1999 Quantitative analysis of growth-related factors in human pituitary adenomas. Lowered insulinlike growth factor-I and its receptor mRNA in growth hormone-producing adenomas. Regulatory Peptides $\mathbf{8 3}$ 31-38. (doi:10.1016/S0167-0115(99)00048-8)

Pickett CA \& Gutierrez-Hartmann A 1994 Ras mediates Src but not epidermal growth factor-receptor tyrosine kinase signaling pathways in GH4 neuroendocrine cells. PNAS 91 8612-8616. (doi:10.1073/pnas.91.18.8612)

Pickett CA, Manning N, Akita Y \& Gutierrez-Hartmann A 2002 Role of specific protein kinase $\mathrm{C}$ isozymes in mediating epidermal growth factor, thyrotropin-releasing hormone, and phorbol ester regulation of the rat prolactin promoter in GH4/GH4C1 pituitary cells. Molecular Endocrinology 16 2840-2852. (doi:10.1210/me.20010305)

Plowman GD, Culouscou JM, Whitney GS, Green JM, Carlton GW, Foy L, Neubauer MG \& Shoyab M 1993 Ligand-specific activation of HER4/p180erbB4, a fourth member of the epidermal growth factor receptor family. PNAS 90 1746-1750. (doi:10.1073/pnas.90.5.1746)

Polk DH, Ervin MG, Padbury JF, Lam RW, Reviczky AL \& Fisher DA 1987 Epidermal growth factor acts as a corticotropin-releasing factor in chronically catheterized fetal lambs. Journal of Clinical Investigation 79 984-988. (doi:10.1172/JCI112910)

Przylipiak A, Kiesel L, Rabe T, Helm K, Przylipiak M \& Runnebaum B 1988 Epidermal growth factor stimulates luteinizing hormone and arachidonic acid release in rat pituitary cells. Molecular and Cellular Endocrinology 57 157-162. (doi:10.1016/0303-7207(88)90045-7)

Radford HM, Avenell JA \& Panaretto BA 1987 Some effects of epidermal growth factor on reproductive function in Merino sheep. Journal of Reproduction and Fertility 80 113-118. (doi:10.1530/jrf.0.0800113)

Renner U, Mojto J, Arzt E, Lange M, Stalla J, Muller OA \& Stalla GK 1993 Secretion of polypeptide growth factors by human nonfunctioning pituitary adenoma cells in culture. Neuroendocrinology 57 825-834. (doi:10.1159/ 000126441)

Roelle S, Grosse R, Aigner A, Krell HW, Czubayko F \& Gudermann T 2003 Matrix metalloproteinases 2 and 9 mediate epidermal growth factor receptor transactivation by gonadotropin-releasing hormone. Journal of Biological Chemistry 278 47307-47318. (doi:10.1074/jbc. M304377200) 
Roh M, Paterson AJ, Asa SL, Chin E \& Kudlow JE 2001 Stage-sensitive blockade of pituitary somatomammotrope development by targeted expression of a dominant negative epidermal growth factor receptor in transgenic mice. Molecular Endocrinology 15 600-613. (doi:10. 1210/me.15.4.600)

Roncaroli F, Nose V, Scheithauer BW, Kovacs K, Horvath E, Young WF Jr, Lloyd RV, Bishop MC, Hsi B \& Fletcher JA 2003 Gonadotropic pituitary carcinoma: HER-2/neu expression and gene amplification. Report of two cases. Journal of Neurosurgery 99 402-408. (doi:10.3171/jns. 2003.99.2.0402)

Samsoondar J, Kobrin MS \& Kudlow JE 1986 Alphatransforming growth factor secreted by untransformed bovine anterior pituitary cells in culture. I. Purification from conditioned medium. Journal of Biological Chemistry 261 14408-14413.

Scheithauer BW, Kurtkaya-Yapicier O, Kovacs KT, Young WF Jr \& Lloyd RV 2005 Pituitary carcinoma: a clinicopathological review. Neurosurgery 56 1066-1074 (discussion 1066-1074). (doi:10.1227/01.NEU. 0000157926.72826.DB)

Schonbrunn A, Krasnoff M, Westendorf JM \& Tashjian AH Jr 1980 Epidermal growth factor and thyrotropinreleasing hormone act similarly on a clonal pituitary cell strain. Modulation of hormone production and inhibition of cell proliferation. Journal of Cell Biology 85 786-797. (doi:10.1083/jcb.85.3.786)

Shah BH, Farshori MP, Jambusaria A \& Catt KJ $2003 a$ Roles of Src and epidermal growth factor receptor transactivation in transient and sustained ERK1/2 responses to gonadotropin-releasing hormone receptor activation. Journal of Biological Chemistry 278 19118-19126. (doi:10.1074/jbc.M212932200)

Shah BH, Soh JW \& Catt KJ 2003b Dependence of gonadotropin-releasing hormone-induced neuronal MAPK signaling on epidermal growth factor receptor transactivation. Journal of Biological Chemistry 278 2866-2875. (doi:10.1074/jbc.M208783200)

Sharma S, Oomizu S, Kakeya T, Masui T, Takeuchi S \& Takahashi S 2003 Gene expression and the physiological role of transforming growth factor-alpha in the mouse pituitary. Zoological Science 20 83-89. (doi:10.2108/zsj. 20.83)

Shaw G, Jorgensen GI, Tweedale R, Tennison M \& Waters MJ 1985 Effect of epidermal growth factor on reproductive function of ewes. Journal of Endocrinology 107 429-436. (doi:10.1677/joe.0.1070429)

Spuch C, Diz-Chaves Y, Perez-Tilve D \& Mallo F 2006

Fibroblast growth factor-2 and epidermal growth factor modulate prolactin responses to TRH and dopamine in primary cultures. Endocrine 29 317-324. (doi:10.1385/ ENDO:29:2:317)

Takahashi S, Sharma S, Oomizu S, Honda J \& Takeuchi S 2002 Intrapituitary regulatory system of mammotrophs in the mouse. Archives of Physiology and Biochemistry 110 34-41. (doi:10.1076/apab.110.1.34.895)

Theodoropoulou M, Arzberger T, Gruebler Y, Jaffrain-Rea ML, Schlegel J, Schaaf L, Petrangeli E, Losa M, Stalla GK \& Pagotto U 2004 Expression of epidermal growth factor receptor in neoplastic pituitary cells: evidence for a role in corticotropinoma cells. Journal of Endocrinology 183 385-394. (doi:10.1677/joe.1.05616)

Vlotides G, Siegel E, Donangelo I, Gutman S, Ren SG \& Melmed S 2008 Rat prolactinoma cell growth regulation by epidermal growth factor receptor ligands. Cancer Research 68 6377-6386. (doi:10.1158/0008-5472.CAN08-0508)

Vlotides G, Cooper O, Chen YH, Ren SG, Greenman Y \& Melmed S 2009 Heregulin regulates prolactinoma gene expression. Cancer Research 69 4209-4216. (doi:10. 1158/0008-5472.CAN-08-4934)

van Wijk PA, van Neck JW, Rijnberk A, Croughs RJ \& Mol JA 1995 Proliferation of the murine corticotropic tumour cell line AtT20 is affected by hypophysiotrophic hormones, growth factors and glucocorticoids. Molecular and Cellular Endocrinology 111 13-19. (doi:10.1016/ 0303-7207(95)03541-E)

Zhang K, Kulig E, Jin L \& Lloyd RV 1993 Effects of estrogen and epidermal growth factor on prolactin and Pit-1 mRNA in GH3 cells. Proceedings of the Society for Experimental Biology and Medicine 202 193-200.

Zhang H, Berezov A, Wang Q, Zhang G, Drebin J, Murali R \& Greene MI 2007 ErbB receptors: from oncogenes to targeted cancer therapies. Journal of Clinical Investigation 117 2051-2058. (doi:10.1172/JCI32278)

Received in final form 26 July 2011

Accepted 13 September 2011

Made available online as an Accepted Preprint 14 September 2011 